\title{
School Libraries and Indexing Policies in Brazil and Portugal
}

\author{
Ana Lúcia Terra*, Mariângela Fujita** \\ and Maria del Carmen Agustín Lacruz*** \\ *Instituto Politécnico do Porto, CETAC.MEDIA, Porto, Portugal, <anaterra@eseig.ipp.pt> \\ **Universidade Estadual Paulista Júlio Mesquita Filho_Campus Marilia, Brazil, \\ $<$ fujita@marilia.unesp.br> \\ ***Universidad de Zaragoza, Zaragoza, Spain < cagustin@unizar.es>
}

\begin{abstract}
Ana Lucia Terra is an adjunct professor in the Superior School of Industrial Studies and Management at Polytechnic Institute of Porto, Portugal, where she teaches an undergraduate course in science and technology of documentation and information, a graduate course in business information, of which she is also the coordinator, and in the specialized postgraduate program in school libraries management. She holds a $\mathrm{PhD}$ in information science from the University of Coimbra, Portugal. Her research areas include information policies, informational behavior as well as organization and management of information.
\end{abstract}

Mariangela Spotti Lopes Fujita is a professor at Sao Paulo State University (UNESP), where she teaches both undergraduate courses in librarianship and archives as well as postgraduate courses in production and organization of information. Fujita has a research grant from the National Research Council for Science and Technology in Brazil to further studies on indexing and indexing languages in the field of information science. She has been serving as Pro-Rector of UNESP University Extension since 2013.

María del Carmen Agustín Lacruz is a professor in the Department of Information Science at the University of Zaragoza, where she teaches various undergraduate courses both in information and documentation as well as in journalism. She holds a PhD from the University of Zaragoza. Her investigation areas are indexing and classification, images, reading and digital inclusion.

Terra, Ana Lúcia , Mariângela Fujita and Maria del Carmen Agustín Lacruz. 2016. "Indexing Policies in Brazilian and Portuguese School Libraries: A Comparative Analysis.” Knowledge Organization 43: 279-284. 7 references.

Abstract: Research data on indexing policies in Brazilian and Portuguese school libraries are presented and discussed. Legal and organizational contexts regarding these types of libraries are briefly described. The collection of empirical data was obtained by means of an inquiry that resulted in 150 questionnaires from Brazil and 406 from Portugal. Based on these samples, a generic identification of school libraries was carried out in terms of teaching levels and institutional/geographical integration. The existence of a catalog in the libraries was also determined. The use of the two main kinds of indexing languages (classification systems and verbal indexing languages) were identified as well as the existence of manuals designed to guide indexing procedures. References are made to aspects related to the specificity and the number of terms/subjects selected for each document and the use of indexing norms by comparing both Brazilian and Portuguese realities.

Received: 23 March 2016; Revised 25 March 2016; Accepted 29 March 2016-03-29

Keywords: school libraries, indexing, use, Brazil, Portugal
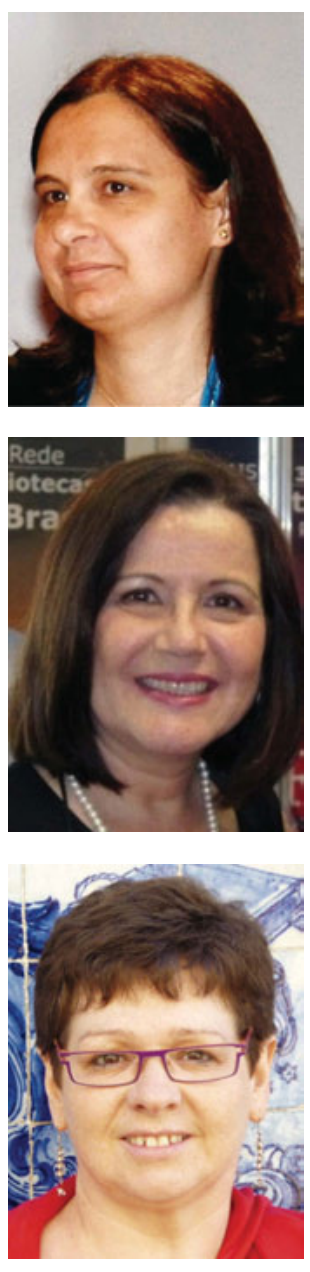

\subsection{Introduction and objectives}

School libraries are information and educational resource centers that foster pedagogical innovation and democratization of knowledge access. Based on these assumptions, Portugal, since the late twentieth century, and Brazil, from
432010 on, have made efforts to create school libraries in or44 der to meet these challenges. In order to fulfill the de45 mands of society, the indexing policy of each information 46 unit and all the aspects it involves - methodologies for de47 scriptive and thematic representation, user studies, among 48 other elements-must adequately contemplate the devel- 
opment of norms and procedures, implementation techniques and indexing evaluation. In short, libraries urgently need to establish processes and indexing procedures and that is why they depend on indexing policies.

Scientific research on school libraries can improve the understanding of this reality and contribute to the development of better services focusing on their users' needs. In this sense, this paper aims to present the results of a survey on the indexing policies practiced in school libraries in Brazil and Portugal. An analysis of the main data gathered by means of an inquiry questionnaire is presented so as to accomplish the following objectives:

1) to identify the indexing languages used in school libraries;

2) to study the cooperation practices among school libraries as to indexing, sharing records or a collective catalog.

3) to analyze aspects related to the indexing specificity performed in school libraries.

\subsection{School libraries}

A school library is an essential component of any educational system and its use is a core element in the teaching and learning processes aimed at the integral education of children and young people so as to enable them to become participant citizens in their community's improvement. Currently, school libraries provide access to collections of various resources both in terms of content scope, support and communication media. In this context, the present study, which is a follow-up research on the indexing instruments used in school libraries (Agustín-Lacruz et al. 2014), discusses some Brazilian and Portuguese initiatives in the topics below.

\subsection{School libraries in Brazil}

In Brazil, the users of school libraries are children and young people aged 4-17 years old, who are legally entitled to a compulsory and free education. In this country, official and government documents establish guidelines and public policy plans, such as the National Plan for School Library (PNBE) of the Ministry of Education. School libraries are an important component in any educational system and as 5 such every school should have one library and at least one 6 librarian. However, the fact is that this has not been im47 plemented in all states and municipalities. Official figures mains precarious." As a matter of fact, there is a shortage of librarians in most libraries; the books sent to schools by the government programs are not always available to readers, and the library spaces are small and sometimes used for other purposes.

In this scenario, two important political actions in favor of school libraries were decisive for the mobilization of educational leaderships: the launching of the "School Library Project: The Construction of an Information Network for Public Education" (Conselho Federal de Biblioteconomia 2008) by the Federal Council of Librarianship (CFB) in conjunction with the Regional Councils of Librarianship (CRB), and the publication of the document "School Library as a Space for Knowledge Production: Parameters for Brazilian School Libraries" (Campello 2010) that provides guidelines for the organization of school library collections. Subsequently, on May 24, 2010, Law numero 12244 was promulgated by the government determining the universal presence of libraries in all Brazilian educational institutions. According to its Article 3, "the country's educational systems should develop progressive efforts to implement the universalization of school libraries, as stated in the Law, within a maximum period of ten years, respecting the librarian profession."

\subsection{School libraries in Portugal}

In Portugal, school libraries began to have a remarkable development in the last decade of the 20th century with the launching of the School Libraries Network (RBE). The $\mathrm{RBE}$ is a Ministry of Education project that started in 1996 and involves local government (municipalities), public libraries and regional education directors under the coordination of the School Libraries Network Office. With this initiative, the government has developed libraries in public schools for each level (from the 1st cycle on) in order to provide access to information and encourage reading habits. It is a phased implementation project whose ultimate goal is to cover all the country's counties and their schools.

By the end of 2008, all schools of the 2nd and 3rd cycles of basic education integrated basic schools and grouping headquarters had integrated libraries. In 2014, the RBE covered about 2500 school libraries (Portugal, 2014). In July 2009, the RBE established the legal post of school librarian with Ordinance 756/2009 which was updated in 2010 and 2011. The aim was to provide human resources to enable school libraries to play their innovative role in school organization and to promote access skills and information use within the educational community. RBE also signed cooperation protocols with City Councils, which will be in charge of providing technical support to secondary and basic schools as well as the sharing of software and bibliographic records. 
A. L. Terra, M. Fujita, M. del Carmen Agustín Lacruz. School Libraries and Indexing Policies in Brazil and Portugal.

\subsection{Indexing policies in Brazilian and Portuguese school libraries: an exploratory study}

Based on both the literature related to indexing and indexing policies and knowledge about school libraries in Brazil and Portugal, in the last quarter of 2012, a survey was carried out in order to verify the methodologies and indexing practices of a sample of school libraries in these two Portuguese-speaking contexts.

\subsection{Research framework and methodology}

To collect the research data for this study, an inquiry questionnaire with 35 questions was devised and adapted to suit the differences between the Brazilian and Portuguese contexts. This adaptation (Terra et al. 2015) involved the creation of two questionnaires: one addressed to the Brazilian context and the other one to the Portuguese context. The inquiry was launched online via SurveyMonkey (www.surveymonkey.com), a specialized tool for inquiry management on the web.

In terms of content, the first questions focused on the general characteristics of a school library (institutional characteristics, educational levels, size of the collection, number of professionals and network integration) and on the existence of a catalog. The next questions addressed the identification of the indexing languages used in the school libraries and the characterization of indexing professionals. Some questions also aimed to determine the use of imported records to the school library OPAC and to ascertain the availability of an indexing procedures manual. The subsequent questions focused on particular aspects of the indexing process, namely the use of some automatic or semi-automatic support, determination of specificity, the existence of guidelines for selecting the number of terms/subjects in a document and the average time for indexing each document. The use of both national and international standards and a system of automatic validation/correction of terms/subjects or the usage of terms without vocabulary control were also discussed. Finally, an indexing evaluation was carried out. The last question allowed respondents to include their comments. In this paper, the more relevant data were selected and analysed.

The answers were collected between November 2012 and May 2013. In the Brazilian questionnaire the first reply was received on November 20, 2012 and the last one on March 30, 2013. As for Portugal, the first reply occurred on November 28, 2012 and the last one on May 23, 2013. The strategy used to launch the inquiry varied between the two countries. In Portugal, a survey of the contacts in school libraries was conducted based on the information available on the School Library Network website in the last 53 quarter of 2012. Messages were sent to 2000 e-mail ad- dresses containing a brief explanation of the survey and the link to the inquiry page.

Because there is no record of school libraries in Brazil, the inquiry was sent to the libraries that integrate the public school networks of Municipal and State Departments. They were selected from the registration list of participants in the "First Brazilian Forum of School Librarianship" sponsored by the Group of Study on Library Schools of the Federal University of Minas Gerais (UFMG) and particularly with the collaboration of the library network coordinator of the State Secretary of Education of Espirito Santo. The municipal networks of Vitoria, Curitiba, Belo Horizonte, Porto Alegre and Sao Paulo participated in this inquiry voluntarily. In Portugal, 406 people started the questionnaire; some questions did not require a compulsory answer. In Brazil 150 people started the questionnaire. In the analysis of the data, percentages were calculated basing on the total number of replies to each question.

\subsection{Generic identification of school libraries}

In Brazil, the sample included eighty-two municipal libraries, eleven state libraries and fifty-seven federal school libraries. In Portugal, the geographical integration of libraries was taken into account; 162 counties were represented in the sample and corresponded to 398 schools. Two answers were invalid and six participants did not answer. One of the distinguishing elements of the libraries is the identification of educational levels, which determines users' characteristics, information needs and, consequently, collection building and organization, including all aspects related to indexing.

In Portugal, 394 libraries identified the school cycles that they served. On the whole, $44.41 \%(\mathrm{n}=175)$ serve only one cycle: $13.96 \%(\mathrm{n}=55)$ the 1 st cycle, $19.80 \%(\mathrm{n}=$ $78)$, the 2 nd cycle and $10.66 \%(n=42)$ the secondary level. However, a higher percentage $(55.83 \%, \mathrm{n}=219)$ of the libraries serve more than one study cycle. In fact, $10.41 \%$ (n $=41)$ cover the four cycles, $22.59 \%(n=89)$ serve the $1 \mathrm{st}$ and $2 \mathrm{nd} / 3 \mathrm{rd}$ cycles and $22.59 \%(\mathrm{n}=89)$ serve the 2nd/3rd cycles as well as the secondary level. Twelve participant libraries did not answer the question.

In Brazil, among the 150 libraries that identified their school cycles, it was found that $0.67 \%(n=1)$ are inserted in the pre-school level, $21.33 \%(\mathrm{n}=32)$ in the primary level and $36 \%(n=54)$ in the secondary level. Therefore, $58 \%(\mathrm{n}=87)$ are concentrated on only one study cycle. The remaining libraries $(42 \%, \mathrm{n}=63)$ cover various study cycles: pre-school, primary and secondary $18 \%(\mathrm{n}=27)$, pre-school and primary $14.67 \%(\mathrm{n}=22)$ and primary and secondary levels $9.33 \%(n=14)$. 


\subsection{Indexing languages}

Data analysis of the indexing languages used in Brazilian and Portuguese school libraries indicated that there is a significant difference between the two countries, which reflects their respective areas of influence and the options found in other types of information units. While the use of the Dewey Decimal Classification (DDC) prevails in Brazil according to $72.4 \%(n=97)$ of the participants' answers, in Portugal almost all the answers $(97.4 \%, \mathrm{n}=370)$ indicated the application of the Universal Decimal Classification (UDC). This expressive predominance of the UDC and $D D C$ shows a preference for a classification system. It was also found that $21.3 \%(\mathrm{n}=81)$ of the sample adopt the Subject Headings List for Libraries, a verbal indexing language. Only $11.1 \%(n=42)$ of the cases use a controlled list of terms elaborated by the library professionals themselves, which presupposes that they can create an indexing language.

Moreover, the use of other indexing languages was only identified in $4.7 \%(n=18)$ of the answers. In this sense, some participants reported using a specific classification tool developed by the International Federation of Film Archives, others mentioned the French document "Principes de classement des documents musicaux," which was adapted to Portuguese in the 1990s. One school reported the use of an arts thesaurus for teaching purposes. In the other cases, simplified adaptations of the UDC were developed internally in the library.

While in Brazil, DDC clearly predominates; this uniformity is not so distinct as in the Portuguese context. $U D C$ is the second most common classification system used in $25.4 \%(n=34)$ of the libraries. Thus, there is a preference for classification systems for knowledge representation. Verbal indexing languages are adopted by a small number of libraries: $17.2 \%(\mathrm{n}=23)$ use their own controlled list terms and $15.7 \%(\mathrm{n}=21)$ resort to the List of Subject Headings for Libraries.

\subsection{Indexing procedures manual}

More than half $(64.9 \%, \mathrm{n}=85)$ of school libraries in Brazil do not have an indexing procedures manual. Nevertheless, in Portugal $41.5 \%(n=145)$ of the participants re5 ported that this material is available. While $30.1 \%(\mathrm{n}=$ 105) do not have any specific indexing guidance tool, they 7 indicated that procedures are included in a general manual 48 that can be applied to the libraries. It should be pointed out
This aspect is relevant both in terms of indexing consistency and mobility of school librarians and other staff as well. On the other hand, it also reflects that effective information services had already been implemented sometime earlier.

Considering that some school libraries are integrated in municipal or other networks and share collective catalogs, it was important to verify whether indexing procedures were available to all the libraries in the network or to each school library individually. Thus, the participants were asked whether an indexing procedures manual was used in their library and, if so, whether this document was available to all the libraries that shared a collective catalog. The data shows that only 44 Brazilians answered this question, a figure that is equivalent to less than one third of the sample. In Portugal, there were 233 answers, which slightly corresponds to more than half of the sample. Among those who answered this question, sharing an indexing manual or a general procedures manual is not a dominant practice for $39.5 \%(n=92)$ of the Portuguese libraries and $29.5 \%(n=13)$ in the case of Brazil.

\subsection{Catalog}

Regarding the availability of a catalog in the school libraries, it was found that this organization and information access tool is present in 71.3\% $(\mathrm{n}=107)$ and in 86.3\% $(\mathrm{n}=$ 340 ) of the Brazilian and the Portuguese libraries, respectively.

As for the Brazilian school library context, one question aimed to know whether a catalog was available and, if so, whether it was manual or electronic. Thus, in $80.3 \%$ ( $\mathrm{n}=$ 86) of the cases it is electronic and in $11.2 \%(n=12)$ it is manual; both types are present in $8.4 \%(n=9)$ of the libraries. This question was not answered by 43 participants.

Considering the importance of collaborative work and the integration of the school libraries in network sharing, it is necessary to know whether a catalog is a tool in such cooperation. In Brazil, while $67 \%(\mathrm{n}=67)$ of the school libraries have their own catalog, $33 \%(n=33)$ use a collective one. This question was not answered by 50 respondents. The same tendency is observed in Portugal, where $58 \%(n=195)$ of the libraries provide a single catalog and $42 \%(n=141)$ use a collective one. There were no answers from 70 respondents. Increasing the number of catalog records could be done by incorporating new records created by the library itself or copied from another catalog or database. It was found that the most common procedure is copying records, as observed in $54.3 \%(\mathrm{n}=70)$ of the Brazilian libraries and in $68.6 \%(n=228)$ of the Portuguese ones. However, it should be noted that in Brazil this tendency is not so strong as in Portugal, for in almost half of the answers $(45.7 \%, \mathrm{n}=59)$ the participants reported 
1 that they did not use this procedure. The use of records al2 ready created and available in other catalogs was reported 3 as a common practice and can contribute to standardize descriptions. However, it may be problematic when the fo5 cus is on content description, because the adaptation to 6 meet the users' needs is imperative. On the other hand, however, this practice also contributes to network coopera8 tion among libraries, such as sharing their tasks in common 9 and rationalization and investments in staff and time. Simultaneously, the use of records copies should be based on the application of principles and rules known and accepted by all in order to ensure quality criteria, indexing uniformity and consistency as well as its products. In this 4 regard, libraries were inquired about the existence of 5 guidelines related to specificity, the number of subjects/terms selected and the use of standards.

\subsection{Guidelines for indexing practice}

Regarding indexing specificity, it was important to know whether guidelines were applied to define how accurate the descriptors were to represent concepts. According to the data, it was found that $45.9 \%(n=56)$ of the Brazilian libraries answered affirmatively; contrary answers were reported by a slightly small number of participants $(44.3 \%, \mathrm{n}$ =54). Only $9.8 \%(\mathrm{n}=12)$ replied that they did not know how to answer the question. As for Portugal, the results were very different: $21.3 \%(n=69)$ of the libraries take indexing specificity into account whereas the majority $(52.8 \%, \mathrm{n}=171)$ do not. About one fourth of the sample $(25.9 \%, \mathrm{n}=84)$ did not know how to answer this question.

One open question asked the participants to give examples of specificity degree in case they applied it. A total of 30 respondents in Brazil and in Portugal sent answers, such as: "it is specific so as to meet the childrens' needs;" "if the document is about 'dogs' it will not be indexed as animals or pets, but as dogs," "children's and young adult's literature - short story, children's and young adult's literaturepoetry;" "black girls, black boys—black children would be used only if the content is about black boys and girls;" "if a book is about trees, then the indexing term must be trees or the specific name of each kind of tree if the book is about specific trees" and "flowers_ - use specific names, for example daisies, violets, roses."

Regarding the number of terms selected to represent the content of each document, the absence of indications was observed in most of the libraries surveyed. According to the participants' answers, this situation corresponds to $72.6 \%(\mathrm{n}=85)$ in Brazil and to $60.7 \%$ in Portugal. In the latter country, it was found that $15,6 \%$ of respondents did not know about the existence of indications in their libraries. The use of standards in the indexing process provides a methodological and conceptual framework for analysis

54 and synthesis of the information content of the items as 55 well as concept selection to determine the scope of the 56 terms. Standards function as guidelines and promote the 57 standardization of practices, aspects particularly relevant to 58 network-based libraries and/or when indexing work is car59 ried out by several people. The analysis of the results 60 showed that the use of standards is not a predominant 61 practice according to the replies of only $42.2 \%(n=49)$ of 62 the Brazilian respondents. On the other hand, 58.5\% ( $\mathrm{n}=$ 63 185) of the Portuguese participants replied that they follow 64 national or international standards in the indexing process. 65 However, it should be emphasized that nearly a quarter $66(22.1 \%, \mathrm{n}=90)$ of the total sample failed to answer this 67 question and 19\% $(\mathrm{n}=60)$ replied that they did not know. 68 Therefore, it seems that school libraries still need to define 69 and improve indexing guidelines practices in relation to 70 specificity, the number of words/subjects selected includ71 ing the use of national or international standards.

72

\subsection{Conclusion}

Considering that indexing is conditioned by procedures, standards, techniques and the choice of indexing languages, among other things, this study aimed to identify and analyze the indexing policies practiced in Brazilian and Portuguese school libraries. Some observations can be made about the results obtained in the sample.

School libraries in Brazil and Portugal are in different stages of development, but both countries emphasize their invaluable contribution to the teaching-learning process. In both countries, classification systems are predominant as indexing languages and are used to represent and physically organize the collection contents. On the other hand, the use of verbal indexing languages is less frequent and the creation or adaptation of languages is almost nonexistent. The fact that Portuguese school libraries started to be articulated through network by the end of last century explains the existence and availability of procedures manuals including topics on indexing. However, the sample showed that in Portugal only one fifth of the surveyed libraries have specific documents with guidelines for indexing. As libraries'experience increases, the formalization of procedures tends to be consolidated. On the other hand, these materials are still used by a minority of school libraries in Brazil as reported by almost half of the participants. In the light of these evidences, further investigations should be carried out in order to analyse the lack of correlation between these two situations.

Taking into account that the establishment of networks for collaborative work is an ever increasing tendency, regarding descriptive cataloguing but also subject analysis, understanding these work procedures is an important issue. Moreover, it can contribute both to the creation of quality 
information access tools, particularly subject search and retrieval and to the necessary support required in the teaching-learning process in order to fulfill the primary function of all school libraries.

\section{References}

Agustín-Lacruz, Mária del Carmen, Mariânegla Spotti Lopes Fujita and Ana Lúcia Terra. 2014. "Linguagens documentais para as bibliotecas escolares: o caso da Espanha, Portugal e Brasil.” Informação \& Sociedade: Estudos 24, no. 3:83-97.

Brasil. Presidência da República. 2010. Lei no 12.244 de 24 de maio de 2010 - Dispõe sobre a universalização das bibliotecas nas instituições de ensino do país. Brasília, DOU de 25 de maio.

Campello, Bernardete, ed. 2010. Biblioteca escolar como espaço de produção do conbecimento: parâmetros para bibliotecas escolares. Belo Horizonte: UFMG, Sistema CFB.

Campello, Bernardete Santos, Vera Lúcia Furst Gonçalves Abreu, Paulo da Terra Caldeira, Ricardo Rodrigues Barbosa, Maria da Conceição Carvalho, Adriana Bogliolo Sirihal Duarte, Carlos Alberto Ávila Araújo, Márcia Mil- ton Vianna, Janaína Ferreira Fialho and Maura Alvarenga. 2011. "Parâmetros para bibliotecas escolares brasileiras." Informação \& Sociedade: Estudos 21, no. 2:10520.

Conselho Federal de Biblioteconomia. 2008. Projeto mobilizador: biblioteca escolar construção de uma rede de informação para o ensino público. Brasília: Sistema CFB/CRB.

Portugal. 2014. Portal RBE: Lista de escolas integradas na RBE por direção de serviços regional. http://www.rbe.mec.pt/ np4/home

Terra, Ana Lúcia, Mariângela Spotti Lopes Fujita and María del Carmen Agustín-Lacruz. 2015. "Políticas de indización en bibliotecas escolares de Brasil y Portugal: análisis comparativo". In XII Congreso ISKO España y II Congreso ISKO España-Portugal, 19-20 de noviembre, 2015, Organización del conocimiento para sistemas de información abiertos, ed. José Vicente Rodríguez Muñoz, Isidoro Gil Leiva, Pedro Manuel Díaz Ortuño and Francisco Javier Martínez Méndez. Murcia: Universidad de Murcia: 470484. http://www.iskoiberico.org/wp-content/uploads/ 2015/11/ISKOEP2015_Actas.pdf 